\title{
Determination of the Corrosion Resistance of SS-304 in Synthetic Seawater at Two Temperatures Using Electrochemical Noise and Polarization Curves
}

\author{
Diego Mendoza Morales, Cecilia Cuevas Arteaga* \\ Research Center in Engineering and Applied Sciences, Autonomous University of the Morelos State, \\ Av. Universidad 1001, Col. Chamilpa, Cuernavaca, Mor., Mexico, C.P. 62209. \\ *E-mail: ccuevas@uaem.mx
}

doi: $10.20964 / 2016.10 .28$

Received: 13 June 2016 / Accepted: 5 August 2016 / Published: 6 September 2016

\begin{abstract}
In this paper two electrochemical techniques were used to study the behavior of Stainless Steel 304 in synthetic seawater. The synthetic seawater was elaborated according to the standard ASTM D 1141-98 (Standard Practice for the preparation of substitute ocean water). Two different temperatures were used in the experiments: room temperature and $40{ }^{\circ} \mathrm{C}$. The electrochemical techniques were potentiodynamic polarization curves and electrochemical noise. The electrochemical noise was analyzed in the time domain and in the frequency domain, the noise resistance $\left(R_{n}\right)$ and the spectral noise resistance $\left(\mathrm{R}_{\mathrm{sn}}^{0}\right)$ were obtained. The corrosion rate at $40{ }^{\circ} \mathrm{C}$ was higher than the corrosion rate at room temperature, but the values of noise resistance and spectral noise resistance were high at both temperatures, indicating the good resistance of the chromium oxide layer to the increment of temperature.
\end{abstract}

Keywords: Stainless Steel 304, Synthetic Seawater, electrochemical noise, potentiodynamic polarization curves.

\section{FULL TEXT}

(C) 2016 The Authors. Published by ESG (www.electrochemsci.org). This article is an open access article distributed under the terms and conditions of the Creative Commons Attribution license (http://creativecommons.org/licenses/by/4.0/). 